Article

\title{
Ecological Assessment, Spatial Analysis, and Potential Sources of Heavy Metals (HMs) in Soils with High Background Values in the Lead-Zinc Mine, Hezhang County, Southwestern China
}

\author{
Fugui Zhang ${ }^{1,2,3} \mathbb{D}$, Chengwen Wang ${ }^{1,2, *}$, Xiaomeng Cheng ${ }^{1,2}$, Honghong Ma ${ }^{1,2}$ and Ling He $1,2,3, *(\mathbb{D})$ \\ 1 Institute of Geophysical \& Geochemical Exploration, Chinese Academy of Geological Sciences, \\ Langfang 065000, China; zfugui@mail.cgs.gov.cn (F.Z.); cxiaomeng@mail.cgs.gov.cn (X.C.); \\ mahonghong@mail.cgs.gov.cn (H.M.) \\ 2 Key Laboratory of Geochemical Cycling of Carbon and Mercury in the Earth's Critical Zone, \\ Chinese Academy of Geological Sciences, Langfang 065000, China \\ 3 College of Earth Sciences, Chengdu University of Technology, Chengdu 610059, China \\ * Correspondence: wchengwen@mail.cgs.gov.cn (C.W.); heling@mail.cgs.gov.cn (L.H.)
}

Citation: Zhang, F.; Wang, C.; Cheng, X.; Ma, H.; He, L. Ecological

Assessment, Spatial Analysis, and Potential Sources of Heavy Metals (HMs) in Soils with High Background Values in the Lead-Zinc Mine, Hezhang County, Southwestern China. Water 2022, 14, 783.

https://doi.org/10.3390/w14050783

Academic Editors: Domenico

Cicchella, Xin Lin and

Alexey Alekseenko

Received: 18 January 2022

Accepted: 28 February 2022

Published: 2 March 2022

Publisher's Note: MDPI stays neutral with regard to jurisdictional claims in published maps and institutional affiliations.

Copyright: (C) 2022 by the authors. Licensee MDPI, Basel, Switzerland. This article is an open access article distributed under the terms and conditions of the Creative Commons Attribution (CC BY) license (https:// creativecommons.org/licenses/by/ $4.0 /)$.

\begin{abstract}
The heavy metals (HMs) usually have high natural background levels in lead-zinc mines. Strengthening the ecological risk assessment and accurate identification sources of HMs is an important component of land resource utilization and food security. A total of 795 soil samples (with a depth of $0 \sim 20 \mathrm{~cm}$ ) were collected in Hezhang County, an area of typical high background levels of HMs with more than 18 large lead-zinc deposits. In this study, inductively coupled plasma emission spectrometry (ICP-OES), inductively coupled plasma mass spectrometry (ICP-MS), atomic fluorescence spectrometry (AFS), and the potentiometric method (POT) were used to test the total concentration of HMs and $\mathrm{pH}$ values. The geographic information system was used to model the concentration distribution of HMs, and the ecological risk was assessed according to the source analysis results. The results suggest that: (1) the mean concentration of $\mathrm{As}, \mathrm{Cd}, \mathrm{Cr}, \mathrm{Cu}, \mathrm{Hg}, \mathrm{Ni}, \mathrm{Pb}$, and $\mathrm{Zn}$ were $24.55,2.25,176.4,89.6,0.19,64.2,102$, and $257 \mathrm{mg} \cdot \mathrm{kg}^{-1}$, respectively, which exceeded the average background value of soils in Guizhou Province by 1.23, 3.41, 1.84, 2.80, 1.73, 1.64, 2.90, and 2.58 times, respectively, and the average concentrations of $\mathrm{Cd}, \mathrm{Cr}, \mathrm{Cu}, \mathrm{Ni}, \mathrm{Pb}$ and $\mathrm{Zn}$ exceed the screening values specified in soil contamination risk in agricultural land; (2) the results of enrichment factor (EF) showed that $29.73 \%$ of Cd are moderately polluted, and other HMs were slightly polluted in a small area or near the baseline value $(\mathrm{EF} \approx 1)$; and $(3) \mathrm{PMF}$ analysis showed that there are five main sources, pyrite, lead-zinc ore, basalt, carbonate rock, and agricultural production, with the risk contribution ratios of $5.25 \%, 27.37 \%, 28.94 \%, 17.91 \%$, and $20.53 \%$, respectively.
\end{abstract}

Keywords: heavy metals; ecological assessment; PMF; source apportionment; lead-zinc mine

\section{Introduction}

Soil is the basis for agricultural production and human survival, and it is also the guarantee for human food and the ecological environment [1]. With the development of industry and the continuous expansion of urbanization in recent years, the problem of soil pollution caused by heavy metals (HMs) has become a hot issue in modern society [2,3]. The HMs with persistent and irreversible characteristics will pose significant risks to human health and the ecosystem [4-6]. When HMs in the soil are transformed into ionic form and enter into the crops, they are then introduced into the human body through the food chain, which may cause serious harmful impacts on human health [7-13]. In view of the above problems, many government departments, such as the United States Environmental Protection Agency (USEPA) and the Ministry of Ecology and Environment of China (MEE), have formulated the maximum allowable limits of HMs in agricultural soils to protect environmental quality and human health [14]. 
China's economy has grown rapidly, with an increasingly prominent soil pollution problem. China has been suffering from severe heavy metals pollution $[9,15,16]$; that is, about 10 million hectares of cultivated land have been polluted by HMs, and 12 million tons of grain by excessive HMs [17]. According to the open report of the China Geological Survey (CGS), the combined proportion of survey spots with moderate and heavy pollution in China accounts for $2.5 \%$, covering an area of $23,300 \mathrm{~km}^{2}$ [18]. The geochemical survey of land quality (GSLQ), as a new national geochemical mapping project implemented by the Ministry of Natural Resources of China, has made significant contributions to the prevention and control of soil pollution, land resource management, agricultural plan structure, and targeted poverty alleviation [11,19-23]. Funded by this project, the ecological risk assessment of HMs has been carried out in Southwest China, where a complex geological background and multiple ecological factors affect the environment. Carbonate and basalt are widely distributed, and HMs have inherent high background levers [24].

The China Cultivated Land Geochemical Survey Report (CCLGSR) shows that the area of polluted cultivated land has been found to total 2.195 million hectares in Southwest China, accounting for $28.9 \%$ of the total polluted cultivated land in China [18]. The GSLQ also confirmed that the high HM background in Southwest China is closely related to the special geological process in this area. Most HMs are in the form of "high background and low bioavailability" [25]. In the natural state, the HM bioavailability is low. However, with the increasing human activities and the changed type of land use, the physical and chemical properties and configuration of soil change, causing the bioavailability of HMs to increase, putting agricultural products at high risk [26]. Therefore, ecological environment risk assessment and contamination sources identification are necessary for bettering the soil environment and protecting human health.

The quantitative identification of the sources of HMs is important for controlling pollutants $[27,28]$. Based on Geographical Information System (GIS), the spatial distribution of HMs can precisely reflect the HMs pollution and identify the "hotspots". The main methods for identifying the sources of heavy metals include principal component analysis (PCA), isotope labeling (IL), multivariate statistical analyses (MSA), cluster analyses (CA), and chemical mass balance (CMB) [29-32], which have their own advantages and disadvantages in practical application [33-35]. To quantify the source of HMs accurately and comprehensively in soil, this study used positive matrix factorization (PMF); the PMF does not need the complex mass spectra, and not only limits the decomposition matrix elements and guarantees the partake rate to be non-negative, but also deals with missing and inaccurate data. The model has been used in the quantitative source apportionment of pollutants in the atmosphere [36,37] and sediment [38-40], and has begun to be used in soil HM source apportionment in the last few years [41,42].

Guizhou Province is located in the southwest of China. Hezhang County, a typical mineral county in Guizhou Province, is the study area. The GSLQ Project shows that the county has the highest concentration of HMs in the soil of Guizhou Province. There are 18 large lead-zinc mines and iron mines, and the old-fashioned activities of zinc smelting have lasted for many years, and with high ecological risk. The emissions of $\mathrm{Cd}$ and $\mathrm{Zn}$ in the study area are high [43], and the concentration of $\mathrm{Pb}$ and $\mathrm{Zn}$ in corn grain exceed the national food limit value [44], which poses potential ecological risks to human health. However, the pollution level and ecological risk in the study area is unknown, and the boundary of ecological risks is unclear, so it is urgent to carry out soil pollution and ecological risk assessment. The three main objectives of this study were (1) to investigate the concentration distribution of HMs in topsoil in Hezhang County, (2) to analyze the potential source of pollution and quantify their contributions using the PMF model combined with geological background, mining activity, and land use investigation, and (3) to assess ecological risks through the distribution and potential sources of HMs. This research elected Hezhang County, with its high geological background and mining activity dual risk, 
as a case study, and will provide information on how the relationship between ecological risks and geological background, parent materials, mining activity, will ensure food security.

\section{Materials and Methods}

\subsection{Study Area}

Hezhang County $\left(104^{\circ} 10^{\prime} \sim 105^{\circ} 01^{\prime} \mathrm{E}, 26^{\circ} 46^{\prime} \sim 27^{\circ} 28^{\prime} \mathrm{N}\right)$, with an area of $3250 \mathrm{~km}^{2}$, is an economically disadvantaged area of Wumeng Mountain at the junction of Guizhou and Yunnan provinces (Figure 1). It is a national-level poverty-stricken county and a key county for poverty alleviation and development identified by the State Council. The terrain is high in the west and low in the east, with an average altitude of $1996 \mathrm{~m}$. It belongs to the warm temperate zone, with an average annual temperature of $12.6^{\circ} \mathrm{C}$ and an average annual rainfall of $885.5 \mathrm{~mm}$. Influenced by bioclimatic conditions and soil parent materials, soil types are complex and diverse. The main soil types in the study area were brown soil, yellow brown soil, red soil, and lime soil. Brown soil accounted for about $72 \%$ of the total soil area in the study area, and all samples collected were silty loam. The mean values of organic matter, $\mathrm{N}, \mathrm{P}$, and $\mathrm{K}$ were $39.59,1.98,1.17$, and $11.50 \mathrm{~g} / \mathrm{kg}$, respectively. The average $\mathrm{pH}$ value of soil was 6.04. The exposed lithology is mainly Emeishan basalt and carbonate rocks, which contain a variety of metallic and non-metallic minerals, of which the iron-mine reserves are 1.08 billion tons, accounting for $50 \%$ of the proven reserves in Guizhou Province, the lead-zinc mine reserves are 7.82 million tons, and the copper mine reserves are 0.38 million tons $[43,44]$. Hezhang County is an indigenous zinc smelting area with a long history, with mining and agriculture as its pillar industries.

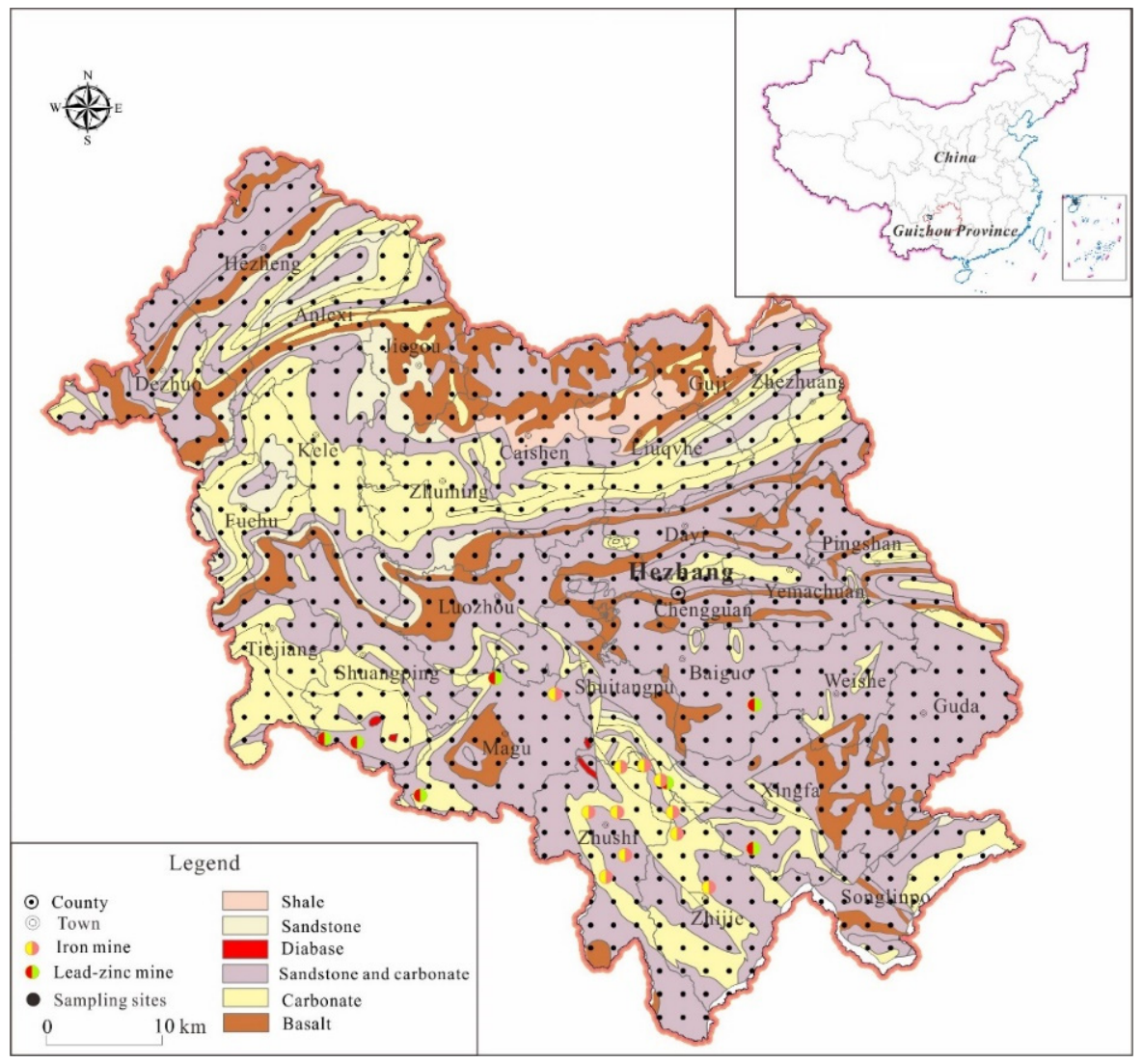

Figure 1. Map of the study area and location of sampling sites. The map of China was downloaded from http:/ /bzdt.ch.mnr.gov.cn/ (accessed on 10 October 2021). 


\subsection{Soil Sampling and Analysis}

In July 2019, a total of 795 topsoil samples (from $0 \sim 20 \mathrm{~cm}$ depth) were collected in the whole county with a grid of $4 \mathrm{~km} \times 4 \mathrm{~km}$. At each site, four to six individual soil samples were collected from an area of approximately $10 \mathrm{~m}^{2}$ and were mixed to form a combined sample. Roots, straws, stones, insects, and other debris were removed from the soil samples. Samples (about $1 \mathrm{~kg}$ dry weight) were packed into cotton bags and transported to the laboratory. The test items were $\mathrm{As}, \mathrm{Cd}, \mathrm{Cr}, \mathrm{Cu}, \mathrm{Hg}, \mathrm{Ni}, \mathrm{Pb}, \mathrm{Zn}$, and $\mathrm{pH}$.

The total concentration of HMs in the soil samples were determined by the analytical center of the Chinese Academy of Geological Sciences. After fully air drying and mixing uniformly, $100 \mathrm{~g}$ of the sample was taken by the quartering method and ground with a planetary ball mill to 200 mesh size. A $0.1 \mathrm{~g}$ sample was weighed and placed in a Teflon crucible, wetted with water, and $\mathrm{HF}, \mathrm{HCl}, \mathrm{HNO}_{3}$, and $\mathrm{HClO}_{4}$ were added, extracted with $\mathrm{HCl}$ to a constant volume to $10 \mathrm{~mL}$, and drawn to the standard curve with three groups of mixed standard solutions in a $10 \% \mathrm{HCl}$ medium solution. According to the quality level of the different analytical methods, the total concentrations of $\mathrm{Cr}$ were determined by inductively coupled plasma emission spectrometry (ICP 7400 RADIAL, Thermo Fisher Scientific, Waltham, MA, USA), and $\mathrm{Pb}, \mathrm{Ni}, \mathrm{Zn}, \mathrm{Cd}$, and $\mathrm{Cu}$ were measured by inductively coupled plasma mass spectrometry (iCAP Qc, Thermo Fisher Scientific, Waltham, MA, USA). The process involved weighing a $0.5 \mathrm{~g}$ sample in a $50 \mathrm{~mL}$ beaker, adding $20 \mathrm{~mL}$ $(1+1)$ of aqua regia, heating and decomposing it on an electric heating plate, extracting with $\mathrm{HCl}$, to a constant volume of $50 \mathrm{~mL}$, and dividing $25 \mathrm{~mL}$ into colorimetric tube. The total concentrations of As and $\mathrm{Hg}$ were determined by atomic fluorescence spectrometry (XGY-2020A, Kaiyuan High Technology Development Company, Langfang, Hebei, China). $\mathrm{pH}$ was tested in solution with a $10.0 \mathrm{~g}$ sample in distilled water without carbon dioxide by potentiometric method (PHBJ-260F, Electrical Scientific Instrument Co., Ltd., Shanghai China). The detection limits of $\mathrm{As}, \mathrm{Cd}, \mathrm{Cr}, \mathrm{Cu}, \mathrm{Hg}, \mathrm{Ni}, \mathrm{Pb}$, and $\mathrm{Zn}$ were $0.2,0.02,1.5,0.1$, $0.0005,0.2,0.2$, and $1 \mathrm{mg} / \mathrm{kg}$, respectively. Twelve national standard reference materials (SRM) (GSS1-GSS12) were inserted blindly and analyzed simultaneously with the samples to control the analytical accuracy and precision. Each sample was measured 12 times, and the logarithmic difference $(\triangle \operatorname{lgC})$ and relative standard deviation (RSD\%) between the average value and the standard value of each measured item was counted. All SRMs met the requirement of a $\Delta \operatorname{lgC}<10 \%$, and all replicates met the requirement of an $\mathrm{RD} \%<10 \%$ in this study. In October 2019, all the testing work had been completed and accepted by the competent authorities, and the analysis and test data are reliable.

\subsection{Statistical and Geostatistical Analyses}

All the geochemical statistics were completed using Microsoft Excel 2020 (Microsoft, Redmond, WA, USA, 2020) and SPSS version 22 for Windows (SPSS Inc., Chicago, IL, USA), the Kolmogorov-Smirnov test was used for assessing the normality of the original concentration data. Moreover, Arcgis version 10.2 (ESRI Inc., Redlands, CA, USA) was used for graphic processing, and source apportionment of the pollutants by PMF model (Ver. 5.0 USEPA).

\subsection{Enrichment Factor}

Enrichment factors (EF), proposed by Buat-Menard and Chesselet in 1979 [45], were used to evaluate the degree of HM pollution, and to assess the degree of human impact. This was calculated as Equation (1):

$$
\mathrm{EF}=\frac{\left(C_{i} / C_{o i}\right)_{\text {sample }}}{\left(C_{i} / C_{o i}\right)_{\text {background }}}
$$

where $C_{i}$ is the concentration of $i$ metal element $(\mathrm{mg} / \mathrm{kg})$, and $C_{o i}$ is the concentration of reference elements in the sediment $(\mathrm{mg} / \mathrm{kg})$. The reference element is generally selected from low volatility elements in the Earth's crust with less artificial pollution, chemical 
stability, and high analytical accuracy. Elements $\mathrm{Ti}, \mathrm{Al}, \mathrm{Fe}, \mathrm{Ca}, \mathrm{Si}$, or $\mathrm{Sc}$ are generally served as acceptable EF reference elements [46-48], and Fe was selected as the reference element since it is one of the major components of the local soil. Six categories were used in the present study: $\mathrm{EF}<1$, no pollution; $1 \leq \mathrm{EF}<2$, slight pollution; $2 \leq \mathrm{EF}<5$, moderate pollution; $5 \leq \mathrm{EF}<20$, significant pollution; $20 \leq \mathrm{EF}<40$, very high pollution; and $40 \leq \mathrm{EF}$, extremely high pollution [49].

\subsection{PMF Model}

PMF has been recommended by USEPA as a general apportionment modeling tool. To solve factor analysis problems, the method of least squares was used in PMF by integrating non-negative constraints into the optimization process and using the error estimate for each data value as a pointwise error estimate [50-52]. Based on the uncertainty of each observation, PMF provides a solution that minimizes the objective function, $Q$. This function is defined as:

$$
\begin{gathered}
X_{i j}=\sum_{K=1}^{P} g_{i k} f_{k j}+e_{i j} \\
Q=\sum_{i=1}^{n} \sum_{j=1}^{m} \frac{e_{i j}{ }^{2}}{u_{i j}}
\end{gathered}
$$

where $x_{i j}$ is a measured variable $j$ in sample $i, g_{i k}$ is the contribution of source $k$ to sample $i$, $f_{k j}$ is the contribution of variable $j$ to source profile $k$ and $e_{i j}$ gives the modeled part of $x_{i j}$, and $p$ is the number of source factors, and where $u_{i j}$ are estimates of the uncertainties in the $j$ th variable measured in the $i$ th sample. When the concentration value of the element was below or equal to the corresponding method detection limit (MDL), use Equation (4) to calculate the uncertainty, otherwise, use Equation (5).

$$
\begin{gathered}
u_{i j}=\frac{5}{6} \times M D L \\
u_{i j}=\sqrt{(\delta \times c)^{2}+\frac{1}{4} M D L^{2}}
\end{gathered}
$$

where $\delta$ is the relative standard deviation, usually $5 \%[53,54]$, and $c$ is the concentration of the element.

\subsection{Potential Ecological Risk Index}

The potential ecological risk index (PERI) was used to assess the degree of HMs and ecological risks in sediment [55]. It is calculated as follows:

$$
\begin{gathered}
E_{r}^{i}=T_{r}^{i} \times \frac{C_{d}^{i}}{C_{l}^{i}} \\
\text { PERI }=\sum_{i=1}^{m} E_{r}^{i}
\end{gathered}
$$

where $C_{d}^{i}$ is the measured concentration of element $i$ in topsoil, and $C_{l}^{i}$ is the corresponding geochemical background reference value in soil. $E_{r}^{i}$ is the PERI of element $i$ in topsoil, and $T_{r}^{i}$ is the toxicity response factor for element $i$, where $T_{r}^{i}$ for $\mathrm{As}=10, \mathrm{Cd}=30, \mathrm{Cr}=2, \mathrm{Cu}=5$, $\mathrm{Hg}=40, \mathrm{Ni}=5, \mathrm{~Pb}=5$, and $\mathrm{Zn}=1$ [56].

The $E_{r}^{i}$ describes the degree of pollution of element $i$, which is divided into five grades, and the PERI a composite value that describes the PERI for multiple pollutants at a given point; this value is divided into four grades [55]: $E_{r}^{i}<40$, low ecolxogical risk; $40 \leq E_{r}^{i}<80$, moderate risk; $80 \leq E_{r}^{i}<160$, strong risk; $160 \leq E_{r}^{i}<320$, quite strong risk; $E_{r}^{i} \geq 320$, extremely strong risk. PERI < 150, low ecological risk; $150 \leq P E R I<300$, moderate risk; $300 \leq P E R I<600$, strong risk; and PERI > 600, quite strong risk. 


\section{Results and Discussion}

\subsection{Concentrations of HMs in Topsoil Samples}

The statistical results of $\mathrm{HMs}(\mathrm{As}, \mathrm{Cd}, \mathrm{Cr}, \mathrm{Cu}, \mathrm{Hg}, \mathrm{Ni}, \mathrm{Pb}$, and $\mathrm{Zn}$ ) and $\mathrm{pH}$ values in topsoil are shown in Table 1 . The mean concentration of target elements exceeded the average background value (ABV) of Guizhou Province [54], which were 1.23, 3.41, 1.84, $2.80,1.73,1.64,2.90$, and 2.58 times the ABV, respectively. Besides As and $\mathrm{Hg}$, the average concentration values of all target elements exceeded the screening values detailed in the risk control standard for the soil contamination of agricultural land (GB 15618-2018), which were $7.50,1.18,1.79,1.07,1.40$, and 1.29 times the screening values, respectively.

Table 1. Summary statistics of trace metal concentrations in topsoil samples.

\begin{tabular}{|c|c|c|c|c|c|c|c|c|c|}
\hline Elements & $\mathrm{pH}$ & As & $\mathrm{Cd}$ & $\mathrm{Cr}$ & $\mathrm{Cu}$ & $\mathrm{Hg}$ & $\mathbf{N i}$ & $\mathrm{Pb}$ & Zn \\
\hline Minimum & 4.63 & 1.23 & 0.25 & 54.3 & 11.4 & 0.03 & 6.3 & 19 & 38 \\
\hline Maximum & 8.12 & 360.25 & 12.72 & 430.8 & 267.7 & 1.68 & 191.6 & 3290 & 4629 \\
\hline Mean & 6.04 & 24.55 & 2.25 & 176.4 & 89.6 & 0.19 & 64.2 & 102 & 257 \\
\hline Median & 5.98 & 17.74 & 1.67 & 172.5 & 83.6 & 0.15 & 65.7 & 41 & 173 \\
\hline Coefficient variation & 0.12 & 1.23 & 0.73 & 0.3 & 0.5 & 0.84 & 0.3 & 3 & 1 \\
\hline Standard deviation & 0.71 & 30.11 & 1.64 & 59.1 & 48.1 & 0.16 & 19.7 & 258 & 358 \\
\hline \multirow[t]{2}{*}{ ABV of Guizhou ${ }^{a}$} & 4.26 & 20 & 0.66 & 95.9 & 32 & 0.11 & 39.1 & 35.2 & 99.5 \\
\hline & $\mathrm{pH}<6.5$ & 40 & 0.3 & 150 & 50 & 1.8 & 70 & 90 & 200 \\
\hline \multirow[t]{2}{*}{ Screening value ${ }^{b}$} & $6.5<\mathrm{pH}<7.5$ & 30 & 0.3 & 200 & 100 & 2.4 & 100 & 120 & 250 \\
\hline & $\mathrm{pH}>7.5$ & 25 & 0.6 & 250 & 100 & 3.4 & 190 & 170 & 300 \\
\hline
\end{tabular}

Note. $\mathrm{N}=795, \mathrm{pH}$ dimensionless quantity, $\mathrm{mg} \cdot \mathrm{kg}^{-1}$ for other elements. ${ }^{\text {a }}$ Soil average background. values of Guizhou Province reported by CNEMC [56]. ${ }^{\mathrm{b}}$ Risk screening values for soil contamination of agricultural land (GB 15618-2018) set by MEE [14].

Enrichment factor (EF) box plot shows (Figure 2) the descending order of EF values were $\mathrm{Cd}(2.33)>\mathrm{Pb}(1.87)>\mathrm{Zn}(1.63)>\mathrm{Cu}(1.61)>\mathrm{Hg}(1.18)>\mathrm{Cr}(1.17)>\mathrm{Ni}(1.02)>\mathrm{As}$ (0.83), and $\mathrm{Cd}$ has a large area of moderate pollution, and $\mathrm{Pb}, \mathrm{Zn}$, and $\mathrm{Cu}$ have a small area of slight pollution. The EF values of $\mathrm{Hg}, \mathrm{Cr}, \mathrm{Ni}$, and $\mathrm{As}$ were near the baseline value $(\mathrm{EF} \approx 1)$, and the contaminations are slight or none. Table 2 shows the statistics of the environmental risk levels of HMs in topsoil. Approximately 40\% EF values of Cd exceed 2, and more than $15 \% \mathrm{EF}$ values of $\mathrm{Pb}, \mathrm{Zn}$, and $\mathrm{Cu}$ were higher than 2, showing moderate or higher pollution. Other HMs are mostly none or slight pollution. Therefore, Hezhang County is a superimposed area with the combined pollution of HMs, which deserves that the academic world and government departments pay particular attention.

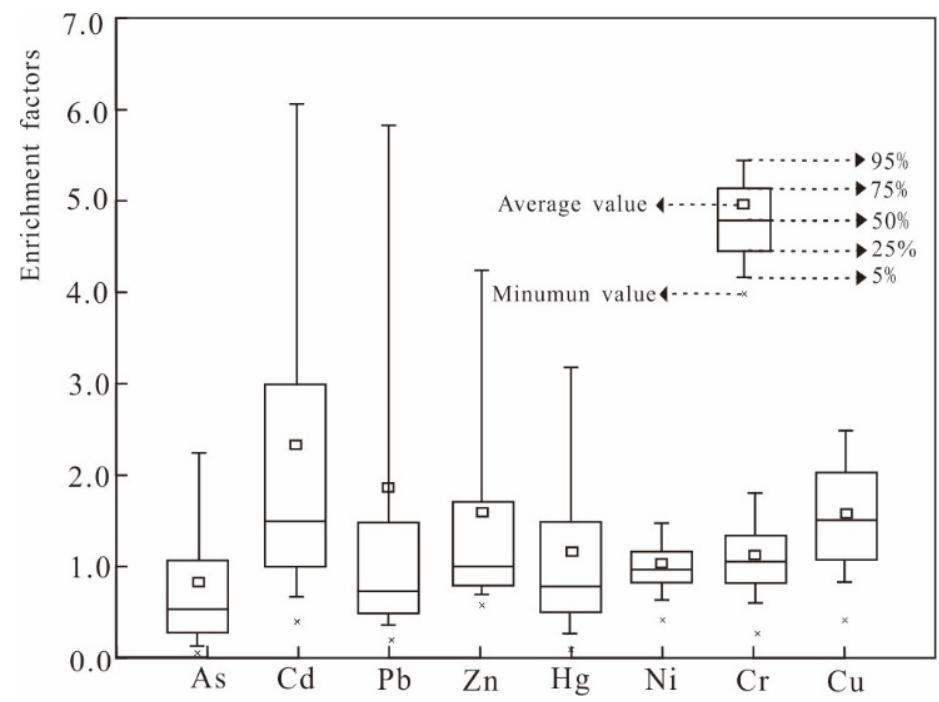

Figure 2. The enrichment factors (EFs) of heavy metals in topsoil. 
Table 2. Environmental risk levels of heavy metals in study area.

\begin{tabular}{|c|c|c|c|c|c|c|c|c|c|c|c|c|}
\hline \multirow[t]{2}{*}{ Elements } & \multicolumn{2}{|c|}{$\begin{array}{c}E F<1 \\
\text { No Pollution }\end{array}$} & \multicolumn{2}{|c|}{$\begin{array}{c}1 \leq \mathrm{EF}<2 \\
\text { Slight Pollution }\end{array}$} & \multicolumn{2}{|c|}{$\begin{array}{l}2 \leq \mathrm{EF}<5 \\
\text { Moderate } \\
\text { Pollution }\end{array}$} & \multicolumn{2}{|c|}{$\begin{array}{c}5 \leq \mathrm{EF}<20 \\
\text { Significant } \\
\text { Pollution }\end{array}$} & \multicolumn{2}{|c|}{$\begin{array}{c}20 \leq \mathrm{EF}<40 \\
\text { Very High } \\
\text { Pollution }\end{array}$} & \multicolumn{2}{|c|}{$\begin{array}{c}40 \leq \mathrm{EF} \\
\text { Extremely High } \\
\text { Pollution }\end{array}$} \\
\hline & $\mathbf{n}$ & $\%$ & $\mathbf{n}$ & $\%$ & n & $\%$ & $\mathrm{n}$ & $\%$ & $\mathrm{n}$ & $\%$ & $\mathbf{n}$ & $\%$ \\
\hline As & 580 & 72.96 & 159 & 20.00 & 48 & 6.04 & 8 & 1.01 & 0 & 0.00 & 0 & 0.00 \\
\hline $\mathrm{Cd}$ & 196 & 24.65 & 279 & 35.09 & 234 & 29.43 & 86 & 10.82 & 0 & 0.00 & 0 & 0.00 \\
\hline $\mathrm{Cr}$ & 299 & 37.61 & 476 & 59.87 & 20 & 2.52 & 0 & 0.00 & 0 & 0.00 & 0 & 0.00 \\
\hline $\mathrm{Cu}$ & 94 & 11.82 & 476 & 59.87 & 225 & 28.30 & 0 & 0.00 & 0 & 0.00 & 0 & 0.00 \\
\hline $\mathrm{Hg}$ & 458 & 57.61 & 221 & 27.80 & 104 & 13.08 & 12 & 1.51 & 0 & 0.00 & 0 & 0.00 \\
\hline $\mathrm{Ni}$ & 388 & 48.81 & 400 & 50.31 & 7 & 0.88 & 0 & 0.00 & 0 & 0.00 & 0 & 0.00 \\
\hline $\mathrm{Pb}$ & 483 & 60.75 & 171 & 21.51 & 92 & 11.57 & 37 & 4.65 & 11 & 1.38 & 1 & 0.13 \\
\hline $\mathrm{Zn}$ & 368 & 46.29 & 295 & 37.11 & 105 & 13.21 & 24 & 3.02 & 3 & 0.38 & 0 & 0.00 \\
\hline
\end{tabular}

Note: $\mathrm{n}$ represents the number of samples for a certain risk level; \% represents the proportion of samples for a certain risk level to the total number of samples.

\subsection{Spatial Distribution of HMs}

The spatial distribution of target elements is presented in Figure 3. These maps illustrated the distinct zones of lower or higher concentrations in the study area. The spatial distribution trends of $\mathrm{Cd}, \mathrm{Hg}, \mathrm{Pb}, \mathrm{Zn}$, and $\mathrm{As}$ were similar and their concentration generally increased from the northern to the southwestern region (Figure $3 a-d, h)$. The high value areas have close relationships with large iron mines and lead-zinc mines in the study area (Figure 3). The components of these mines are mainly $\mathrm{Cd}, \mathrm{Pb}, \mathrm{Zn}$, and $\mathrm{Fe}$, and are accompanied by $\mathrm{Cu}, \mathrm{Hg}$, and As. There are varying degrees of mineralization around the parent rock, including hematitization, pyritization, and carbonation. HMs enter the soil with natural subsidence and water leaching, resulting in enrichment. The soil parent rocks are mainly carbonate rock (Figure 3i), and HMs have natural high background properties, so secondary enrichment is easy to occur in the process of carbonate weathering. The spatial distributions of $\mathrm{Cr}, \mathrm{Cu}$, and $\mathrm{Ni}$ are very similar, and there was a "hotspot" area observed in the central and northern regions with high concentrations (Figure $3 \mathrm{e}-\mathrm{g}$ ). Apparently, $\mathrm{Cr}, \mathrm{Cu}$, and $\mathrm{Ni}$ have the same source and are affected by basalt in the study area (Figure $3 \mathrm{i}$ ). $\mathrm{Cr}, \mathrm{Ni}$, and $\mathrm{Cu}$, as the iron family elements, have similar geochemical properties and behaviors. The high value areas of $\mathrm{Cd}, \mathrm{Cr}$, and $\mathrm{Cu}$ are distributed in the junctions of townships (Figure $3 \mathrm{e}-\mathrm{g}$ ), which indicate the influence of human activity.

\subsection{Sources Identification of HMs}

The correlation analysis is an effective approach to reflect the possible sources of HMs. The correlation coefficients $(r$ ) between $\mathrm{HMs}(\mathrm{As}, \mathrm{Cd}, \mathrm{Cr}, \mathrm{Cu}, \mathrm{Hg}, \mathrm{Ni}, \mathrm{Pb}$, and $\mathrm{Zn}$ ) and $\mathrm{Fe}$ concentration are shown in Table 3. The high correlation coefficients between HMs are used to measure the correlation degree. The high correlation coefficients were observed between $\mathrm{As}$ and $\mathrm{Pb}, \mathrm{Pb}$ and $\mathrm{Zn}$, and $\mathrm{As}$ and $\mathrm{Zn}$ at 0.01 levels $(r>0.8)$, which indicate they may have a common origin. The correlation coefficients between $\mathrm{Cr}$ and $\mathrm{Hg}$ are greater than 0.5 $(r=0.506)$. The correlation coefficients among $\mathrm{Cd}, \mathrm{Hg}, \mathrm{As}, \mathrm{Pb}$, and $\mathrm{Zn}$ are greater than 0.2 at 0.01 levels $(r>0.2)$, which suggest they may have the same contamination sources.

$\mathrm{Cr}, \mathrm{Ni}, \mathrm{Cu}$, and $\mathrm{Fe}$, as the iron group elements, are commonly siderophile. The correlation coefficients are high among these elements. The high concentrations of $\mathrm{Cr}, \mathrm{Ni}$, and $\mathrm{Cu}$ are closely related to large areas of exposed basalt, and that of $\mathrm{Fe}_{2} \mathrm{O}_{3}$ represents an important product of the weathering of the parent rock. It is speculated that the high concentrations of $\mathrm{Cr}, \mathrm{Ni}$, and $\mathrm{Cu}$ may be caused by the influence of lithology.

To further identify and quantify the sources and contributions of HMs in soils, in this paper, the PMF 5.0 model was used to explore the main sources of pollution. The input data set includes eight species and 795 samples. Uncertainty estimates of species and samples were provided by the analytical lab. To make sure the model is reasonable, HMs were set as strong $(\mathrm{As}, \mathrm{Cu}, \mathrm{Ni}, \mathrm{Pb}, \mathrm{Zn})$ and weak $(\mathrm{Cd}, \mathrm{Cr}, \mathrm{Hg})$ according to their signal-to-noise ratios 
$(\mathrm{S} / \mathrm{N})$ and the residual variance and concentration scatter plot. The number of factors is set as $3,4,5$, and 6 , the number of runs was set to 20 and a random start number was selected. When setting the number of factors to 5, the runs converged and the $Q$ values were stable.
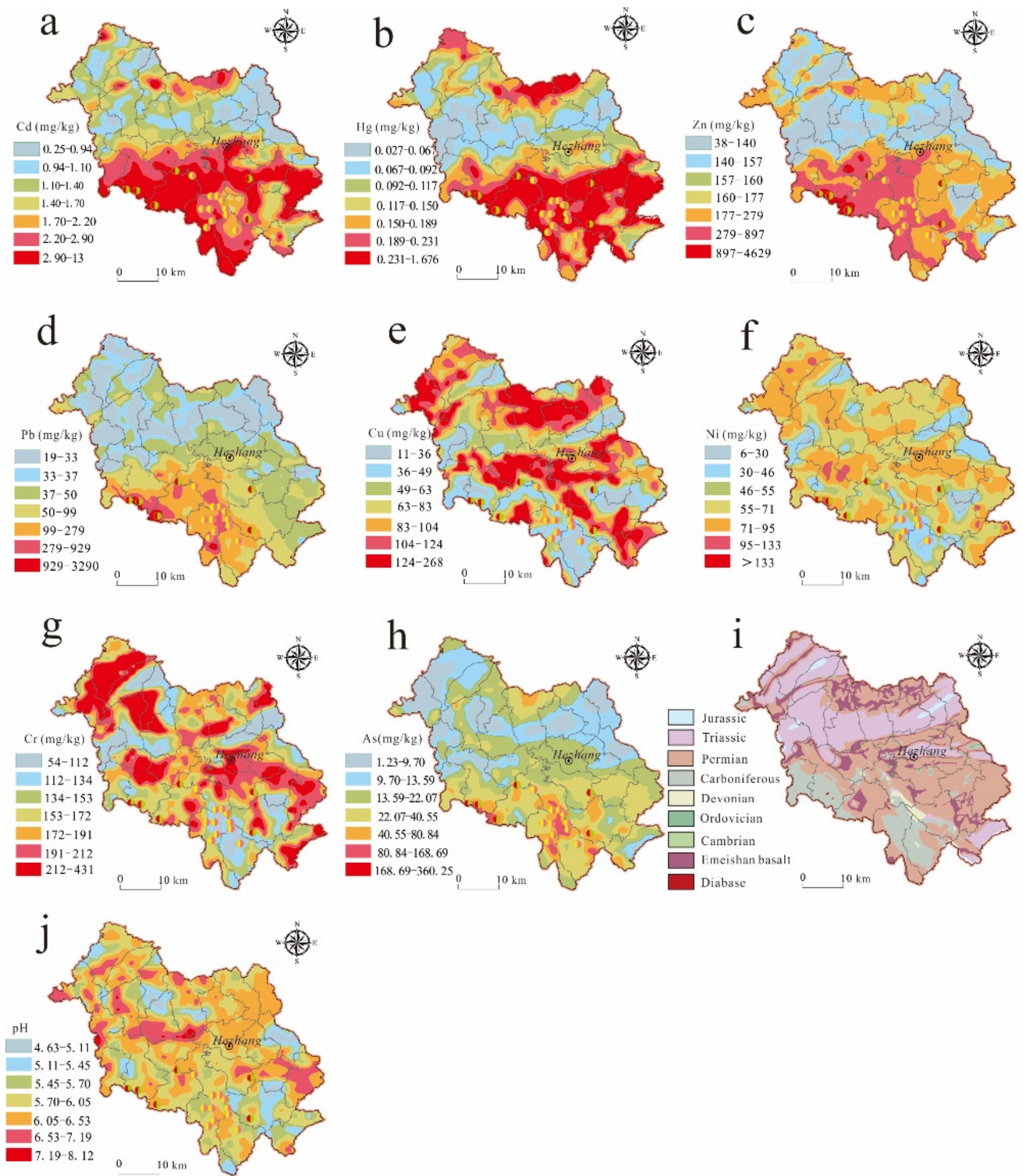

Figure 3. Spatial distribution of (a) $\mathrm{Cd}$, (b) $\mathrm{Hg}$, (c) $\mathrm{Zn}$, (d) $\mathrm{Pb},(\mathbf{e}) \mathrm{Cu},(\mathbf{f}) \mathrm{Ni}$, (g) $\mathrm{Cr}$, (h) As, (j) pH, and (i) geological map of study area. Note: in study area, Late Permian Emeishan formation is dominated with greyish-green dense, amygdaloidal basalt, and other formations are mainly composed of limestone and dolomite. 
Table 3. Pearson correlations matrix for heavy metal concentrations in topsoil.

\begin{tabular}{|c|c|c|c|c|c|c|c|c|c|}
\hline Elements & As & $\mathrm{Cr}$ & $\mathrm{Cu}$ & $\mathrm{Ni}$ & $\mathrm{Pb}$ & $\mathrm{Zn}$ & $\mathrm{Fe}_{2} \mathrm{O}_{3}$ & $\mathrm{Cd}$ & $\mathrm{Hg}$ \\
\hline As & 1 & & & & & & & & \\
\hline $\mathrm{Cr}$ & -0.041 & 1 & & & & & & & \\
\hline $\mathrm{Cu}$ & 0.047 & $0.256^{* *}$ & 1 & & & & & & \\
\hline $\mathrm{Ni}$ & -0.004 & $0.801^{* *}$ & $0.435^{* *}$ & 1 & & & & & \\
\hline $\mathrm{Pb}$ & $0.905^{* *}$ & -0.038 & 0.065 & 0.008 & 1 & & & & \\
\hline $\mathrm{Zn}$ & $0.825^{* *}$ & 0.010 & $0.100 * *$ & $0.082 *$ & $0.942^{* *}$ & 1 & & & \\
\hline $\mathrm{Fe}_{2} \mathrm{O}_{3}$ & 0.022 & $0.408^{* *}$ & $0.879^{* *}$ & $0.595^{* *}$ & 0.064 & $0.108^{* *}$ & 1 & & \\
\hline $\mathrm{Cd}$ & $0.206^{* *}$ & $0.096^{* *}$ & $-0.094^{* *}$ & $0.175^{* *}$ & $0.220^{* *}$ & $0.294 * *$ & $-0.099 * *$ & 1 & \\
\hline $\mathrm{Hg}$ & $0.357^{* *}$ & 0.015 & $-0.070^{*}$ & 0.027 & $0.289^{* *}$ & $0.291^{* *}$ & $-0.093^{* *}$ & $0.506^{* *}$ & 1 \\
\hline
\end{tabular}

Note. ${ }^{* *}$ Correlation is significant at $p<0.01$ (two-tailed); ${ }^{*}$ Correlation is significant at $p<0.05$ (two-tailed).

The source profile and source contribution ratios of HMs are shown in Table 4. The contribution ratio of As in Factor 1 is $77 \%$, which is much larger than other HMs. As is usually accompanied by pyrite, and will inevitably enter the environment. During the weathering process, as in the arsenic-containing waste residue, filling material and smelting residue was leached and activated, and it may be released into the surrounding environment, causing As pollution in the atmosphere, water, and soil. The pollution level of As is low and the range is small, mainly distributed in the mining area. Factor 1 denotes the pollution source of mining pyrite.

Table 4. Source profile and source contribution ratios for different heavy metals by PMF.

\begin{tabular}{ccccccccccc}
\hline \multirow{2}{*}{ Elements } & \multicolumn{4}{c}{ Source Profiles/mg $\mathbf{~ k g - 1 ~}$} & \multicolumn{4}{c}{ Source Contribution Ratios/\% } \\
\cline { 2 - 10 } & Factor 1 & Factor 2 & Factor 3 & Factor 4 & Factor 5 & Factor 1 & Factor 2 & Factor 3 & Factor 4 & Factor 5 \\
\hline $\mathrm{As}$ & 18.91 & 1.88 & 0.00 & 3.50 & 0.26 & 77.0 & 7.7 & 0.0 & 14.2 & 1.0 \\
$\mathrm{Cr}$ & 4.01 & 1.59 & 108.48 & 8.94 & 45.01 & 2.4 & 0.9 & 64.6 & 5.3 & 26.8 \\
$\mathrm{Cu}$ & 3.30 & 0.26 & 0.03 & 76.25 & 9.88 & 3.7 & 0.3 & 0.0 & 85.0 & 11.0 \\
$\mathrm{Ni}$ & 1.84 & 1.19 & 40.35 & 0.00 & 20.69 & 2.9 & 1.9 & 63.0 & 0.0 & 32.3 \\
$\mathrm{~Pb}$ & 1.53 & 68.42 & 4.98 & 7.19 & 9.53 & 1.7 & 74.7 & 5.4 & 7.8 & 10.4 \\
$\mathrm{Zn}$ & 6.31 & 113.46 & 43.97 & 25.15 & 54.91 & 2.6 & 46.5 & 18.0 & 10.3 & 22.5 \\
$\mathrm{Cd}$ & 0.00 & 0.41 & 0.13 & 1.32 & 0.10 & 0.0 & 20.7 & 6.7 & 67.4 & 5.3 \\
$\mathrm{Hg}$ & 0.0063 & 0.0014 & 0.0149 & 0.1317 & 0.0115 & 3.8 & 0.8 & 9.0 & 79.4 & 6.9 \\
\hline
\end{tabular}

$\mathrm{Pb}, \mathrm{Zn}$, and $\mathrm{Cd}$ have high contribution rates in Factor 2, with contribution rates of $74.7 \%, 46.5 \%$, and $20.7 \%$, respectively. Wastewater, mineral dust, and slag generated during lead and zinc smelting processes could be the main sources of pollution. $\mathrm{Pb}, \mathrm{Zn}$ and $\mathrm{Cd}$ contamination can be found in soil near the lead-zinc deposit. Cd pollution is caused by the lead-zinc deposit with high $\mathrm{Cd}$. $\mathrm{Pb}$ and $\mathrm{Zn}$ were extracted, and $\mathrm{Cd}$ was not recycled and was released into the environment during smelting. Therefore, Factor 2 can be explained as the human pollution caused by lead-zinc mining.

$\mathrm{Cr}$ and $\mathrm{Ni}$ have high contribution rates in Factor 3, with contribution rates of $64.6 \%$ and $63.0 \%$, respectively. $\mathrm{Cr}$ and $\mathrm{Ni}$, as the iron group elements, are commonly siderophile. The correlation coefficients are high among these elements. The high concentrations of $\mathrm{Cr}$ and $\mathrm{Ni}$ are closely related to large areas of exposed basalt. Factor 3 can be explained as the natural source caused by large-area exposure of basalt.

In factor 4, Cu, Cd, and $\mathrm{Hg}$ have higher contribution rates than the other elements, and the contribution ratio of $\mathrm{Pb}, \mathrm{Zn}$, and $\mathrm{Cd}$ were $85.0 \%, 67.4 \%$, and $79.4 \%$, respectively. Soil $\mathrm{pH}$ is one of the most important chemical properties. Alkaline soil is less in the study area, and acidic soil is more. In the high acidified zone, the concentrations of $\mathrm{Al}^{3+}$ and $\mathrm{Al}(\mathrm{OH})^{2+}$ are generally high, the $\mathrm{Al}^{3+}$ is more likely to occupy the position where $\mathrm{Cd}$ is adsorbed, which resulted in a high concentration of $\mathrm{Cd}$ in soil [57]. The soil parent rocks are mainly carbonate rocks, and HMs such as $\mathrm{Cd}$ and $\mathrm{Hg}$ have a natural high background, secondary enrichment is easy to occur in the process of carbonate weathering. The high 
value areas of $\mathrm{Cu}$ are closely related to large areas of exposed basalt. The fourth factor was a natural source. Therefore, both factor 3 and factor 4 could be explained as natural sources.

For the fifth factor, $\mathrm{Ni}, \mathrm{Cr}$, and $\mathrm{Zn}$ have high contribution rates and the contribution ratios were $32.3 \%, 26.8 \%$, and $22.5 \%$, respectively. In Hezhang, as an agricultural county, the high value distribution of $\mathrm{Ni}, \mathrm{Cr}$, and $\mathrm{Zn}$ coincides with the distribution of farming. Manure and wastewater are directly discharged into the surrounding environment, HMs accumulate in soils. In addition, fertilizers, pesticides, and agricultural supplies are also the main sources of HMs in agricultural soil. The accumulation of $\mathrm{Cd}$ is also related to the input of agricultural supplies. Therefore, factor 5 mainly comes from agricultural production.

Based on the above discussion, there are five sources of HMs in Hezhang County, namely pyrite mining, lead-zinc mining, natural source (basalt), natural source (carbonate), and agriculture production. The risk contribution ratios of the five sources of HMs are $5.25 \%, 27.37 \%, 28.94 \%, 17.91 \%$, and $20.53 \%$, respectively (Figure 4 ). Both pyrite mining and lead-zinc mining are industrial emissions, which was consistent with the fact that mining is a pillar industry in Hezhang County, and the total risk contribution ratio was $32.62 \%$. Both factor 3 and factor 4 could be defined as natural sources, which coincided with the distribution of parent rocks, and the total risk contribution ratio was $46.85 \%$. Factor 5 mainly comes from agricultural production, as agriculture is a pillar industry in the study area.

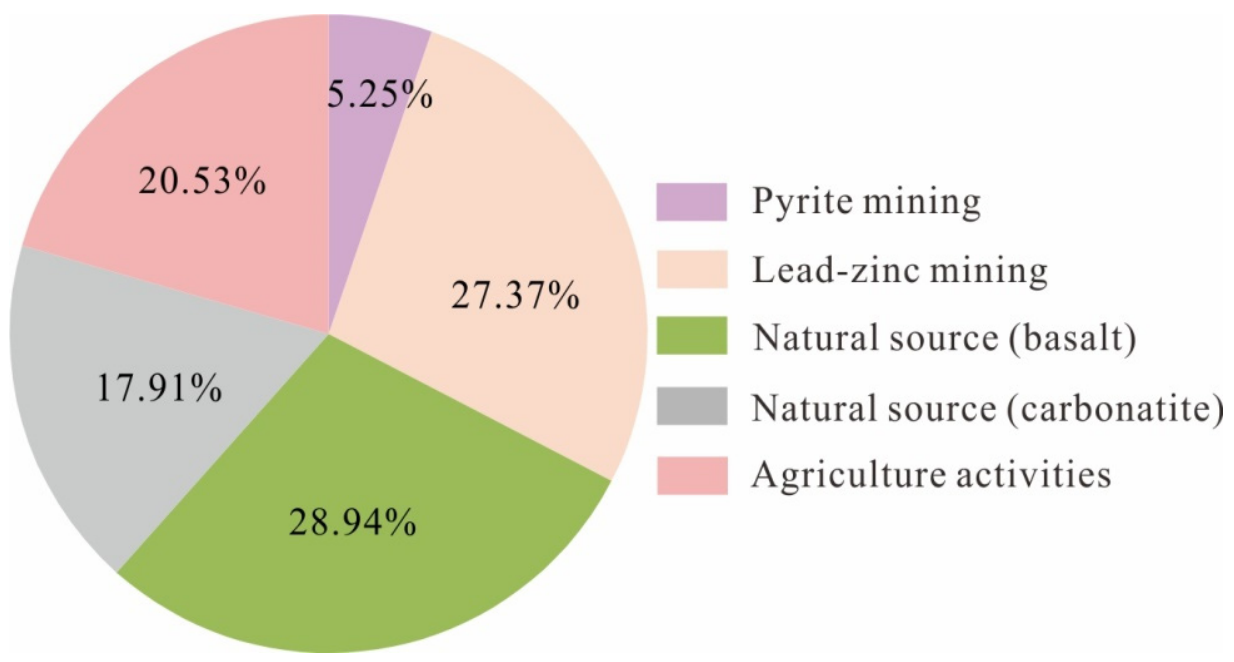

Figure 4. Factor contributions of potential ecological risk.

\subsection{Ecological Risk Assessment}

The PERI of HMs in topsoil were shown in Table 5. It was obvious that 297 sampling sites presented low ecological risk $(P E R I<150), 341$ sampling sites presented moderate risk $(150 \leq P E R I<300)$, 136 sampling sites presented strong risk $(300 \leq P E R I<600)$, and 21 sampling sites presented quite strong risk $(P E R I>600)$, accounting for 37.36\%, $42.89 \%, 17.11 \%$, and $2.64 \%$ of the total number of samples, respectively. The average PERI is calculated for each set of 50 samples, and the ecological risks of all sampling sites exceed 300, with five sets of sampling sites over 600 (Figure 5a). The descending order of PERI values was $\mathrm{Cd}>\mathrm{Hg}>\mathrm{Cu}>\mathrm{As}>\mathrm{Ni}>\mathrm{Pb}>\mathrm{Cr}>\mathrm{Zn}$, with contribution rates of $44.22 \%$, $31.67 \%, 7.57 \%, 5.15 \%, 4.89 \%, 3.40 \%, 2.09 \%$, and $1.01 \%$, respectively. $\mathrm{Hg}$ and $\mathrm{Cd}$ were the main risk elements because of high toxicity coefficients and enrichment factors (Figure $5 b$ ).

The ecological risk of $\mathrm{Cd}$ and $\mathrm{Hg}$ in the study area was evaluated by the integrating ArcGIS 10.2. The spatial distribution of different ecological risk level of $\mathrm{Cd}, \mathrm{Hg}$, and the comprehensive ecological risk level for eight types of HMs in Hezhang county are presented in Figure 6. Cd pollution was serious in Hezhang County (Figure 6a); of the total sampling sites, only $9.56 \%$ have slight pollution risk, and the proportions of moderate risk, strong risk, quite strong risk and extremely strong risk are $42.39 \%, 31.45 \%, 14.59 \%$, 
and $2.01 \%$, respectively (Table 5). Figure 6a shows that quite strong risk-extremely strong risk is primarily distributed in Magu, Shuangping, Guda, Zhushi, Weishe, and Chengguan. According to the study, the large iron and lead-zinc mine areas are mainly located near the junction of these townships, and mining activity can lead to the leakage of $\mathrm{Cd}$ into the environment. The ecological risk of $\mathrm{Hg}$ is less than $\mathrm{Cd}$; of the total sampling sites, $33.71 \%$ have slight pollution risk, and the proportions of moderate risk, strong risk, quite strong risk and extremely strong risk are $38.11 \%, 23.65 \%, 3.52 \%$, and $1.01 \%$, respectively (Table 5). The ecological risk regions remain identical for $\mathrm{Hg}$ pollution and $\mathrm{Cd}$ pollution, and are also distributed (Figure $6 \mathrm{~b}$ ). The spatial distribution of $\mathrm{Hg}$ has a strong similarity with that of $\mathrm{Cd}$, and the areas with high ecological hazard coefficients are mainly distributed in the large iron and lead-zinc mine areas.

Table 5. Assessment on potential ecological risk of heavy metals in the study area.

\begin{tabular}{|c|c|c|c|c|c|}
\hline $\begin{array}{c}\text { Elements } \\
\text { HMs }\end{array}$ & $\begin{array}{c}P E R I<150 \\
\text { low ecological risk } \\
\mathrm{n}(\%) \\
297(37.36)\end{array}$ & \multicolumn{2}{|c|}{$\begin{array}{c}150 \leq P E R I<300 \\
\text { moderate risk } \\
\mathrm{n}(\%)\end{array}$} & $\begin{array}{c}300 \leq P E R I<600 \\
\text { strong risk } \\
\mathrm{n}(\%) \\
136(17.11)\end{array}$ & $\begin{array}{c}600 \leq P E R I \\
\text { quite strong risk } \\
\mathrm{n}(\%) \\
21(2.64)\end{array}$ \\
\hline \multicolumn{6}{|c|}{$E_{r}^{i}$} \\
\hline Elements & $\begin{array}{c}E_{r}^{i}<40, \\
\text { low ecological risk } \\
\mathrm{n}(\%)\end{array}$ & $\begin{array}{c}40 \leq E_{r}^{i}<80 \\
\text { moderate risk } \\
\mathrm{n}(\%)\end{array}$ & $\begin{array}{c}80 \leq E_{r}^{i}<160, \\
\text { strong risk } \\
\mathrm{n}(\%)\end{array}$ & $\begin{array}{c}160 \leq E_{r}^{i}<320 \\
\text { quite strong risk } \\
\mathrm{n}(\%)\end{array}$ & $\begin{array}{c}E_{r}^{i} \geq 320, \\
\text { extremely strong risk } \\
\mathrm{n}(\%)\end{array}$ \\
\hline $\mathrm{Cd}$ & $76(9.56)$ & $337(42.39)$ & $250(31.45)$ & $116(14.59)$ & $16(2.01)$ \\
\hline $\mathrm{Hg}$ & $268(33.71)$ & $303(38.11)$ & $188(23.65)$ & $28(3.52)$ & $8(1.01)$ \\
\hline
\end{tabular}

Note: $\mathrm{n}$ represents the number of samples for a certain risk level; \% represents the proportion of samples for a certain risk level to the total number of samples.
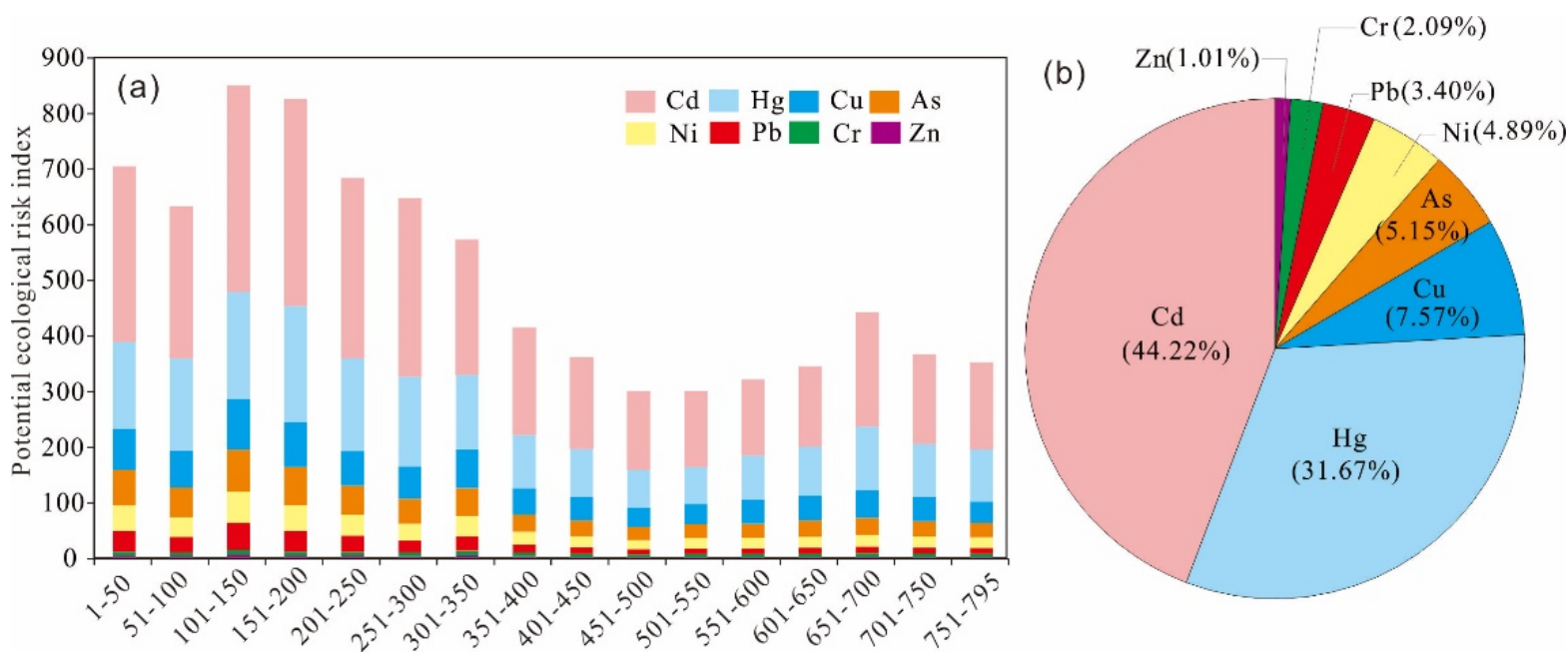

Figure 5. Total potential ecological risk assessment of HMs in the sampling sites (a), and the contribution of HMs to potential ecological risks (b).

The spatial distribution of the comprehensive ecological risk index shows that areas with slight ecological risk, moderate risk, strong risk, and quite strong risk to the total sampling sites are $37.36 \%, 42.89 \%, 17.11 \%$, and $2.64 \%$, respectively (Table 5). The spatial distribution of strong risk and quite strong risk are mainly distributed in the large iron and lead-zinc mine areas, and is highly consistent with $\mathrm{Cd}$ and $\mathrm{Hg}$ (Figure 6c). 


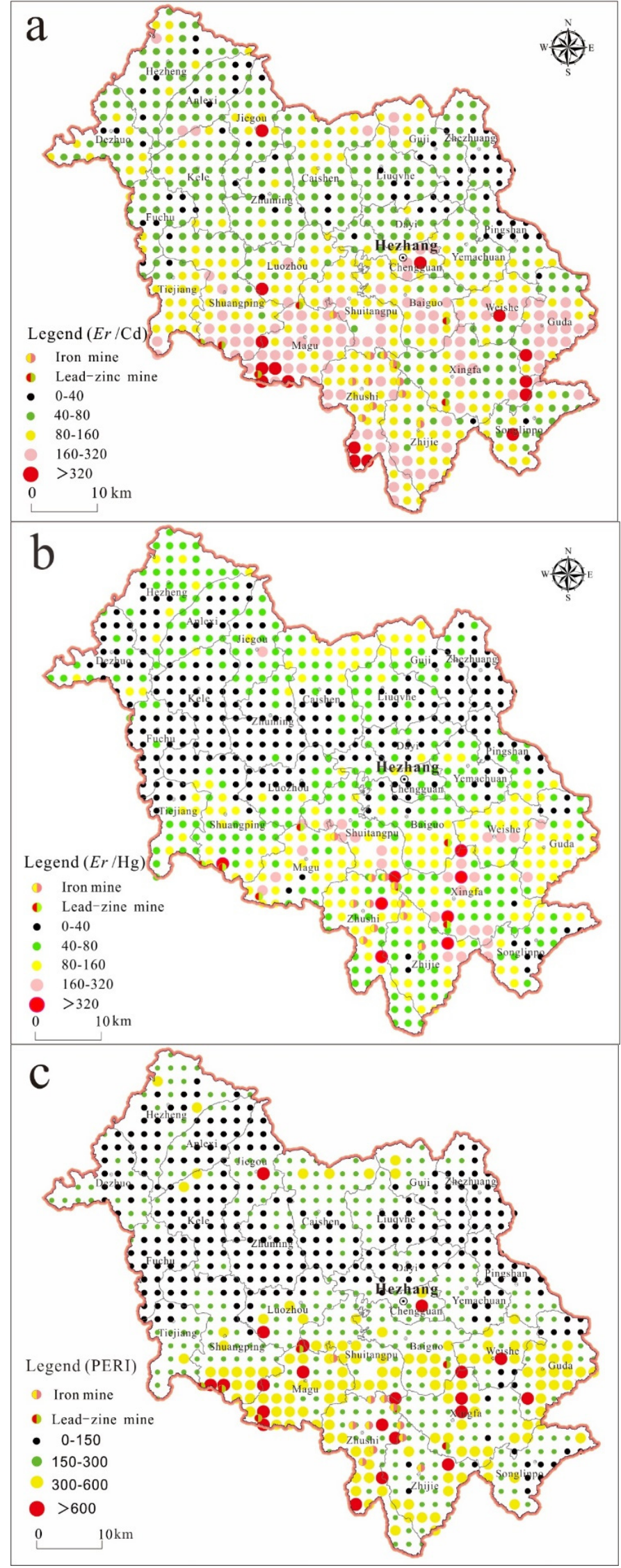

Figure 6. Spatial distribution of potential ecological risks of $\mathrm{Cd}(\mathbf{a}), \mathrm{Hg}(\mathbf{b})$ and eight heavy metals (c) in study area. 


\section{Conclusions}

The mean concentrations of HMs in topsoil are higher than the ABV of Guizhou Province, and the average concentrations of $\mathrm{Cd}, \mathrm{Cr}, \mathrm{Cu}, \mathrm{Ni}, \mathrm{Pb}$, and $\mathrm{Zn}$ exceed the screening values specified in the risk control standard for soil contamination of agricultural land (GB 15618-2018), indicating HMs accumulated in the topsoil. The high value areas of Cd, $\mathrm{Hg}, \mathrm{Pb}, \mathrm{Zn}$, and As are closely related to large iron and lead-zinc mines in the study area, and $\mathrm{Cr}, \mathrm{Cu}$, and $\mathrm{Ni}$ are highly consistent with the distribution of the basalt, which were affected by mining and soil parent rocks. The EFs show that $\mathrm{Cd}$ has a large area of moderate pollution, $\mathrm{Pb}, \mathrm{Zn}$, and $\mathrm{Cu}$ have a small area of slight pollution, the EFs values of $\mathrm{Hg}, \mathrm{Cr}, \mathrm{Ni}$, and $A s$ are near the baseline value $(E F \approx 1)$, and the contaminations are in slight or none. The PERI indicates that low ecological risk, moderate risk, strong risk, and quite strong risk account for $37.36 \%, 42.89 \%, 17.11 \%$, and $2.64 \%$ of the total number of samples, respectively. The PMF indicates there are five sources, namely pyrite mining, lead-zinc mining, natural source (basalt), natural source (carbonate), and agricultural production, with contribution rates of $5.25 \%, 27.37 \%, 28.94 \%, 17.91 \%$, and $20.53 \%$, respectively. The results show that the mining activities have caused serious environmental pollution. The local government should prohibit growing agricultural products in lead-zinc mining areas and encourage people to cultivate more plants that have super accumulation and enrichment of HMs. Scientific measures should be taken to control soil acidification and activation of HMs and ensure the safe use of land.

Author Contributions: Conceptualization, methodology, writing-Original Draft, F.Z., C.W. and L.H.; software, F.Z. and X.C.; investigation, and visualization, F.Z. and H.M.; data curation, X.C. and H.M.; validation and formal analysis, F.Z., X.C. and H.M.; writing-review and editing, F.Z. and C.W.; supervision, L.H. All authors have read and agreed to the published version of the manuscript.

Funding: This research was supported by the Geochemical Survey of Land Quality Project (Grant No. DD20160313, DD20190522).

Institutional Review Board Statement: Not applicable.

Informed Consent Statement: Not applicable.

Data Availability Statement: The data presented in this study are available on request from the corresponding author. The processed data are not publicly available as the data also form part of an ongoing study.

Conflicts of Interest: The authors declare no conflict of interest.

\section{References}

1. Drobnik, T.; Greiner, L.; Keller, A.; Grêt-Regamey, A. Soil quality indicators—from soil functions to ecosystem services. Ecol. Indic. 2018, 94, 151-169. [CrossRef]

2. Zhu, L.; Liu, J.; Xu, S.; Xie, Z. Deposition behavior, risk assessment and source identification of heavy metals in reservoir sediments of Northeast China. Ecotoxicol. Environ. Saf. 2017, 142, 454-463. [CrossRef] [PubMed]

3. Hu, W.; Zhang, Y.; Huang, B.; Teng, Y. Soil environmental quality in greenhouse vegetable production systems in eastern China: Current status and management strategies. Chemosphere 2017, 170, 183-195. [CrossRef]

4. Liang, J.; Feng, C.; Zeng, G.; Gao, X.; Zhong, M.; Li, X.; Li, X.; He, X.; Fang, Y. Spatial distribution and source identification of heavy metals in surface soils in a typical coal mine city, Lianyuan, China. Environ. Pollut. 2017, 225, 681-690. [CrossRef]

5. Yu, L.; Zhang, F.; Zang, K.; He, L.; Wan, F.; Liu, H.; Zhang, X.; Shi, Z. Potential Ecological Risk Assessment of Heavy Metals in Cultivated Land Based on Soil Geochemical Zoning: Yishui County, North China Case Study. Water 2021, 13, 3322. [CrossRef]

6. Mwesigye, A.R.; Young, S.D.; Bailey, E.H.; Tumwebaze, S.B. Population exposure to trace elements in the Kilembe copper mine area, Western Uganda: A pilot study. Sci. Total Environ. 2016, 573, 366-375. [CrossRef]

7. Giller, K.E.; McGrath, S.P. Pollution by toxic metals on agricultural soils. Nature 1988, 335, 676. [CrossRef]

8. Liu, X.; Yu, T.; Yang, Z.F.; Hou, Q.Y.; Yang, Q.; Li, C.; Ji, W.B.; Li, B.; Duan, Y.R.; Zhang, Q.Z.; et al. Transfer mechanism and bioaccumulation risk of potentially toxic elements in soil-rice systems comparing different soil parent materials-ScienceDirect. Ecotoxicol. Environ. Saf. 2021, 216, 112214. [CrossRef]

9. Cheng, S. Heavy metal pollution in China: Origin, pattern and control. Environ. Sci Pollut. Res. 2003, 10, 192-198. [CrossRef] 
10. Naveed, M.; Tanvir, B.; Wang, X.K.; Brtnicky, M.; Ditta, A.; Kucerik, J.; Subhani, Z.; Nazir, M.Z.; Radziemska, M.; Saeed, Q.; et al. Co-composted biochar enhances growth, physiological, and phytostabilization efficiency of brassica napus and reduces associated health risks under chromium stress. Front. Plant Sci. 2021, 12, 775785. [CrossRef]

11. Cheng, H.; Li, M.; Xie, X.J. Exploring China: Environment and resources. J. Geochem. Explor. 2014, 139, 1-3. [CrossRef]

12. Chen, H.; Teng, Y.; Lu, S.; Wang, Y.; Wang, J. Contamination features and health risk of soil heavy metals in China. Sci. Total Environ. 2015, 512-513, 143-153. [CrossRef] [PubMed]

13. Ullah, I.; Ditta, A.; Jan, A.U.; Rizwan, M.S.; Rizwan, M. Assessment of health and ecological risks of heavy metal contamination: A case study of agricultural soils in Thall, Dir-Kohistan. Environ. Monit. Assess. 2020, 192, 786. [CrossRef] [PubMed]

14. MEE (Ministry of Ecology and Environment of the People's Republic of China). Soil Environment Quality Risk Control Standard for Soil contamination of Agriculture Land (GB 15168-2018); China Environment Publishing Group: Beijing, China, 2018.

15. Gu, Q.B.; Yang, Z.F.; Yu, T.; Yang, Q.; Hou, Q.Y.; Zhang, Q.Z. From soil to rice-A typical study of transfer and bioaccumulation of heavy metals in China. Acta Agric. Scand. Sect. B 2018, 68, 631-642. [CrossRef]

16. Wang, Q.; Dong, Y.; Cui, Y.; Liu, X. Instances of soil and crop heavy metal contamination in China. Soil Sediment Contam. 2001, 10, 497-510. [CrossRef]

17. Teng, Y.; Ni, S.; Wang, J.; Zuo, R.; Yang, J. A geochemical survey of trace elements in agricultural and non-agricultural topsoil in Dexing area, China. J. Geochem. Explor. 2010, 104, 118-127. [CrossRef]

18. China Cultivated Land Geochemical Survey Report. Available online: http://www.cgs.gov.cn/upload/201506/20150626/gdbg pdf (accessed on 25 June 2015).

19. Cheng, H.; Li, K.; Li, M.; Yang, K.; Liu, F.; Cheng, X. Geochemical background and baseline value of chemical elements in urban soil in China. Front. Earth Sci. 2014, 21, 265-306. [CrossRef]

20. Cheng, H.; Li, M.; Zhao, C.; Yang, K.; Li, K.; Peng, M.; Yang, Z.; Liu, F.; Liu, Y.; Bai, R.; et al. Concentrations of toxic metals and ecological risk assessment for sediments of major freshwater in China. J. Geochem. Explor. 2015, 157, 15-26. [CrossRef]

21. Li, K.; Peng, M.; Zhao, C.; Yang, K.; Zhou, Y.; Liu, F.; Tang, S.; Yang, F.; Han, W.; Yang, Z.; et al. Vicennial Implementation of Geochemical Survey of Land Quality in China. Front. Earth Sci. 2019, 26, 128-158. [CrossRef]

22. Li, M.; Xi, X.; Xiao, G.; Cheng, H.; Yang, Z.; Zhou, G.; Ye, J.; Li, Z. National multi-purpose regional geochemical survey in China. J. Geochem. Explor. 2014, 139, 21-30. [CrossRef]

23. Peng, M.; Zhao, C.; Ma, H.; Yang, Z.; Yang, K.; Liu, F.; Li, K.; Yang, Z.; Tang, S.; Guo, F.; et al. Heavy metal and Pb isotopic compositions of soil and maize from a major agricultural area in Northeast China: Contamination assessment and source apportionment. J. Geochem. Explor. 2019, 208, 106403. [CrossRef]

24. Duan, Y.R.; Yang, Z.F.; Yu, T.; Liu, X.; Ji, W.B.; Jiang, H.Y.; Zhuo, X.X.; Wu, T.S.; Qin, J.X.; Wang, L. Geogenic cadmium pollution in multi-medians caused by black shales in Luzhai, Guangxi. Environ. Pollut. 2020, 260, 113905. [CrossRef] [PubMed]

25. Wen, Y.B.; Li, W.; Yang, Z.F.; Zhang, Q.Z.; Ji, J.F. Enrichment and source identification of Cd and other heavy metals in soils with high geochemical background in the karst region, Southwestern China. Chemosphere 2020, 245, 125620. [CrossRef] [PubMed]

26. Tu, C.; He, T.; Liu, C.; Lu, X. Effects of land use and parent materials on trace elements accumulation in topsoil. J. Environ. Qual. 2013, 42, 103-110. [CrossRef]

27. Zhao, Y.; Wang, Z.; Sun, W.; Huang, B.; Shi, X.; Ji, J. Spatial interrelations and multi-scale sources of soil heavy metal variability in a typical urban-rural tran-sition area in Yangtze River Delta region of China. Geoderma 2010, 156, 216-227. [CrossRef]

28. Pan, Y.; Wang, Y. Atmospheric wet and dry deposition of trace elements at 10 sites in Northern China. Atmos. Chem. Phys. 2015, 15, 951-972. [CrossRef]

29. Li, S.; Zhang, Q. Response of dissolved trace metals to land use/land cover and their source apportionment using a receptor model in a subtropic river, China. J. Hazard Mater. 2011, 190, 205-213. [CrossRef] [PubMed]

30. Huang, J.; Cheng, W.; Shi, Y.; Zeng, G.; Yu, H.; Gu, Y.; Shi, L.; Yi, K. Honeycomblike carbon nitride through supramolecular preorganization of monomers for high photocatalytic performance under visible light irradiation. Chemosphere 2018, 211, 324-334. [CrossRef]

31. Luo, X.; Xue, Y.; Wang, Y.; Cang, L.; Xu, B.; Ding, J. Source identification and apportionment of heavy metals in urban soil profiles. Chemosphere 2005, 127, 152-157. [CrossRef]

32. Nanos, N.; Rodríguez Martin, J.A. Multiscale analysis of heavy metal contents in soils: Spatial variability in the Duero river basin (Spain). Geoderma 2012, 189-190, 554-562. [CrossRef]

33. Huang, J.; Li, F.; Zeng, G.; Liu, W.; Huang, X.; Xiao, Z.; Wu, H.; Gu, Y.; Li, X.; He, X.; et al. Integrating hierarchical bioavailability and population distribution into potential eco-risk assessment of heavy metals in road dust: A case study in Xiandao District, Changsha city, China. Sci. Total Environ. 2016, 541, 969-976. [CrossRef] [PubMed]

34. Huang, J.; Peng, S.; Mao, X.; Li, F.; Guo, S.; Shi, L.; Shi, Y.; Yu, H.; Zen, G. Source apportionment and spatial and quantitative ecological risk assessment of heavy metals in soils from a typical Chinese agricultural county. Process. Saf. Environ. 2019, 126, 339-347. [CrossRef]

35. Pan, H.; Lu, X.; Lei, K. A comprehensive analysis of heavy metals in urban road dust of Xi'an, China: Contamination, source apportionment and spatial distribution. Sci. Total Environ. 2017, 609, 1361-1369. [CrossRef] [PubMed]

36. Alleman, L.Y.; Lamaison, L.; Perdrix, E.; Robache, A.; Galloo, J. PM10 metal concentrations and source identification using positive matrix factorization and wind sectoring in a French industrial zone. Atmos. Res. 2010, 96, 612-625. [CrossRef] 
37. Amil, N.; Latif, M.T.; Khan, M.F.; Mohamad, M. Seasonal variability of PM2.5 composition and sources in the Klang Valley urban-industrial environment. Atmos. Chem. Phys. 2016, 16, 5357-5381. [CrossRef]

38. Pekey, H.; Doğan, G. Application of positive matrix factorisation for the source apportionment of heavy metals in sediments: A comparison with a previous factor analysis study. Microchem. J. 2013, 106, 233-237. [CrossRef]

39. Chen, H.; Teng, Y.; Wang, J.; Song, L.; Zuo, R. Source apportionment of sediment PAHs in the Pearl River Delta region (China) using nonnegative matrix factorization analysis with effective weighted variance solution. Sci. Total Environ. 2013, 444, 401-408. [CrossRef]

40. Comero, S.; Vaccaro, S.; Locoro, G.; Capitani, L.D.; Gawlik, B.M. Characterization of the Danube River sediments using the PMF multivariate approach. Chemosphere 2014, 95, 329-335. [CrossRef]

41. Xue, J.; Zhi, Y.; Yang, L.; Shi, J.; Zeng, L.; Wu, L. Positive matrix factorization as source apportionment of soil lead and cadmium around a battery plant (Changxing County, China). Environ. Sci. Pollut. Res. 2014, 21, 7698-7707. [CrossRef]

42. Schaefer, K.; Einax, J.W. Source apportionment and geostatistics: An outstanding combination for describing metals distribution in soil. CLEAN-Soil Air Water 2016, 44, 877-884. [CrossRef]

43. Bi, X.Y.; Feng, X.B.; Yang, Y.G.; Qiu, G.L.; Li, G.H.; Li, F.L.; Liu, T.Z.; Fu, Z.Y.; Jin, Z.S. Environmental contamination of heavy metals from zinc smelting areas in Hezhang County, western Guizhou, China. Environ. Int. 2006, 32, 883-890. [CrossRef]

44. Bi, X.Y.; Feng, X.B.; Yang, Y.G.; Qiu, G.L.; Li, G.H. Quantitative assessment of cadmium emission from zinc smelting and its influences on the surface soils and mosses in Hezhang County, Southwestern China. Atmos. Environ. 2006, 40, 4228-4233. [CrossRef]

45. Buat-Menard, P.; Chesselet, R. Variable influence of the atmospheric flux on the trace metal chemistry of oceanic suspended matter. Earth Planet Sci. Lett. 1979, 42, 399-411. [CrossRef]

46. Hsu, C.; Chiang, H.; Lin, S.; Chen, M.; Lin, T.; Chen, Y. Elemental characterization and source apportionment of PM10 and PM2.5 in the western coastal area of central Taiwan. Sci. Total Environ. 2016, 541, 1139-1150. [CrossRef] [PubMed]

47. Kara, M.; Dumanoglu, Y.; Altiok, H.; Elbir, T.; Odabasi, M.; Bayram, A. Spatial distribution and source identification of trace elements in topsoil from heavily industrialized region, Aliaga, Turkey. Environ. Monit. Assess. 2014, 186, 6017-6038. [CrossRef]

48. Szolnoki, Z.; Farsang, A.; Puskas, I. Cumulative impacts of human activities on urban garden soils: Origin and accumulation of metals. Environ. Pollut. 2013, 177, 106-115. [CrossRef]

49. Sutherland, R.A. Bed sediment-associated trace metals in an urban stream, Oahu. Hawaii. Environ. Geol. 2000, 39, 611-627. [CrossRef]

50. Paatero, P.; Tapper, U. Positive matrix factorization: A non-negative factor model with optimal utilization of error estimates of data values. Environmetrics 1994, 5, 111-126. [CrossRef]

51. Kim, E.; Hopke, P.K.; Edgerton, E.S. Improving source identification of Atlanta aerosol using temperature resolved carbon fractions in positive matrix factorization. Atmos. Environ. 2004, 38, 3349-3362. [CrossRef]

52. Begum, B.A.; Kim, E.; Biswas, S.K.; Hopke, P.K. Investigation of sources of atmospheric aerosol at urban and semi-urban areas in Bangladesh. Atmos. Environ. 2004, 38, 3025-3038. [CrossRef]

53. Eunhwa, J.; Mohammed, S.A.; Roy, M.H. Source apportionment of polycyclic aromatic hydrocarbons in urban air using positive matrix factorization and spatial distribution analysis. Atmos. Environ. 2013, 79, 271-285. [CrossRef]

54. Guan, Q.; Wang, F.; Xu, C.; Pan, N.; Lin, J.; Zhao, R.; Yang, Y.; Luo, H. Source apportionment of heavy metals in agricultural soil based on PMF: A case study in Hexi Corridor, northwest China. Chemosphere 2017, 193, 189-197. [CrossRef]

55. Hakanson, L. An ecological risk index for aquatic pollution control. a sedimentological approach. Water Res. 1980, 14, 975-1001. [CrossRef]

56. CNEMC (China National Environmental Monitoring Centre). The Backgrounds of Soil Environment in China; China Environmental Science Press: Beijing, China, 1990.

57. Zhang, F.G.; Pen, M.; He, L.; Ma, H.H. Sources identification, ecological risk assessment, and controlling factors of potential toxic elements in typical lead-zinc mine area, Guizhou province, Southwest China. Environ. Sci. 2022, 43, 385-397. [CrossRef] 